These arrangenents involved the presentation of eighteen communications, and of a number of subjects that were presented informally.

The average attenlance at the meetings during the year exhibits a substantiated increase as compared with the several years immediately preceding. A number of the topics presenter afforded acceptable material for the lonmal.

The publication of the Monthly Bulletin has been continued as heretofore, and notwithstanding its consideralile cost, the Committee believes it would be very unwise to discontin ue it.

Several important suljects presented at the neetings have given cause for the appointment of special committees for their consideration, and it is anticipated that the investigations of these committees will prove of substantial value.

WASHINGTON JONKS, Chaimian.

\title{
ANNUAL REPORT OF THE CHEMICAL SECTION FOR THE
} YFAR IgOI.

\section{To the Committec on Sictional Amongements.}

During the year Ign the Chemical Section held seven stated meetings, . at which the following subjects were presented and discussed:

Dr. W. J. Williams. "What Constitutes an Explosive?"

Mr. Lymatn F. Kel,ler. "What does the Designation C.P. Mean?" "A New Method for Chromic Acid and the Soluable Chromates;" "A Communication on Walnut Oi1."

Prof. F. W. Clarke. "The Chemical Work of the U. S. Geological Survey."

Mr. W. Fi. Ridenour. "The Chemistry of Deposits in Steam Boilers ;" "The Estimation of Caustic in the Presence of Alkali Carbonate."

Dr. Jos. W. Richards. "Some Abridgements of Chemical Calculations."

Dr. Robert H. Bradbury. "Some of the Researches of Professor Spring, of Iriége ;" "The Goldschmidt Process for the Reduction of Certain Metals and the Production of High Temperatures."

Dr. I. F. Keller. "Moissan's Work on Fluorine and the Fluorine Compounds ;" "The Shimer Crucible for Carbon Combustions."

In addition to the above, several of the meetings were devoted to the exhibition of numerous new and interesting chemical lecture experiments (Drs. Keller, Jradbury, I,effmann aud Sadtler). Mr. Wn. McDevitt presented some instructive experiment's suggested by explosions at fires; and Dr. Keller showed and commented on a fine series of lantern-slides illustrative of historical chemistry.

The membership of the Section has been fully maintained, and the general interest of the nembers continues unabated.

The program for the first semester of 1902 is of unusual interest.

HARRY F. KELLER, Chairman of Execulive Committee. 